\title{
EFFECT OF SERVICE HOUR CHANGES ON HEALTH CARE QUALITY AND PATIENT SATISFACTION AT MUARA BUNGO HOSPITAL
}

\author{
Oneng Soekiraten, Prastuti Soewondo
}

Faculty of Public Health, Universitas Indonesia

\begin{abstract}
Background: Recently the service hours has been changed at the Muara Bungo Hospital. The impetus for change in the delivery hours of care has come from the patient's perspective. This study aimed to determine the effect of service hour changes on patient satisfaction at the Muara Bungo Hospital.

Subjects and Method: An analytic study was conducted at Muara Bungo Hospital. A total of 30 patients was selected for this study. The dependent variable was patient satisfaction. The independent variable was service hour changes by adding 2 hours and 15 minutes. The data were collected by in-depth interview, observation, and documentation from the suggestion box. The data were analyzed using descriptive analysis.

Results: Patient satisfaction increased with the additional 2 hours and 15 minutes time from the previous service hours.

Conclusion: Patient satisfaction increases with the additional 2 hours and 15 minutes time from the previous service hours at Muara Bungo Hospital.
\end{abstract}

Keywords: service hour, hospital, patient, satisfaction

\section{Correspondence:}

Oneng Soekiraten. Faculty of Public Health, Universitas Indonesia, Depok.

Email: oneng.carol@gmail.com. Mobile: 0811741980.

\section{BACKGROUND}

The development of the health sector is currently experiencing a lot of changes and progress, including in Indonesia, one of which is the field of hospital. The hospital is an integrated and comprehensive health service implementing unit, which has a large enough role to improve health status. To deal with the intense competition in providing quality health care products for the public as consumers, of course hospitals can not escape the marketing aspects in order to be able to satisfy patients' needs and expectations. Various efforts will be sought by hospital managers to create quality service quality, including through quality management mechanisms and providing good services and appropriate medical actions.

The Hanafie Muara Bungo hospital is owned by the Bungo Regency Government, it has been established in stages since 1980 at the cost of the Central Government and was completed in 1982, located above 8.5 Ha, and starting operational November 1982, class D with initial capacity with 50 beds, at in 2013 also received a recommendation from Governor Decree Number 71 regarding Referral hospitals. Hanafie Muara Bungo Regional General Hospital A class of hospital from Type B has been established with a capacity of 228 beds, located in the capital city of Bungo Regency which is in Muara 
Bungo which is about $300 \mathrm{~km}$ from the city of Padang and $258 \mathrm{~km}$ from the city of Jambi which is passed by Jalan Lintas Sumatera, H. Hanafie Muara Bungo Regional General Hospital became a referral hospital for neighboring districts such as Sarolangun, Merangin, Tebo (Jambi Province), and Dhamasraya (West Sumatra Province).

H. Hanafie hospital has 14 polyclinics which in the implementation of health services are carried out by specialist doctors. Previously carrying out health services with the following conditions: (1) Monday to Thursday (a) Taking queue numbers at 08.00 to 10.00 ; (b) Registration of outpatients at 08.00 to 10.00; (c) Outpatient services at 09.00 to 12.00; (2) Friday; (a) Taking queue numbers from 08.00 to 10.00; (b) Registration of outpatients at 08.00 to 10.00; (c) Outpatient services at 09.00 a.m. to 11.00; (3) Saturday; (a) Taking queue numbers from 08.00 to 10.00; (b) Registration of outpatients at 08.00 to 10.00 ; (c) Outpatient services at 09.00 to 12.00.

With the provisions of the hours of the servants, there are still many who have not implemented it optimally, sometimes the doctors or other officers have left their assignments before the service hours are over. Based on the results of Table 1. The results of suggestion box processing suggestion boxes available at H. Hanafie hospital found several complaints with the same problem and happened repeatedly, namely about the hours of service in a polyclinic that is too short so that it cannot get specialized services optimally.

\section{SUBJECTS AND METHOD}

\section{Study Design}

This was a qualitative study, with a case study approach. This study was carried out at the H. Hanafie General Hospital in the outpatient unit, comparing before and after the service hour policy.

\section{Study Informant}

A total of 30 informants consist of directors, heads of services, five outpatient officers, five specialists, and eighteen patients were selected for this study.

\section{Data Analysis}

The data were obtained using indepth interviews, observation, and documentation. The technique of analyzing data is data collection, data presentation, data reduction, data collection, and conclusions.

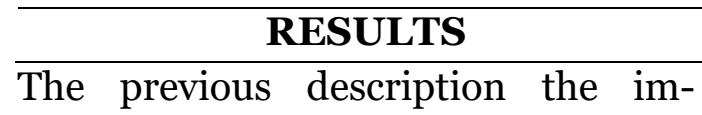
provement in service hours policy in the Outpatient Unit, the results obtained from the suggestion box.

\begin{tabular}{clc}
\hline Name & \multicolumn{1}{c}{ Complaints } & $\begin{array}{c}\text { Service } \\
\text { Rating }\end{array}$ \\
\hline Sutriyanto & $\begin{array}{l}\text { The services of the nurses have no work ethic, speak } \\
\text { disrespectfully in serving the patient's family, we deeply } \\
\text { regret this incident. }\end{array}$ & Poor \\
Zola & $\begin{array}{l}\text { Bad security service. Indecent speak, it's useless if the security } \\
\text { guard acts like that. Please handle our complaint. Thank you. }\end{array}$ & Poor \\
\hline
\end{tabular}




\begin{tabular}{|c|c|c|}
\hline Cawang & $\begin{array}{l}\text { Uncomfortable when waiting for the doctor in the clinic room. } \\
\text { The air conditioner was not working. }\end{array}$ & Adequate \\
\hline Paijo & $\begin{array}{l}\text { It's too late to arrive because of the distance, the neurologist } \\
\text { does not want to serve. Remember that the doctor's mission is } \\
\text { to serve, not to be served. }\end{array}$ & Poor \\
\hline $\begin{array}{l}\text { Dika } \\
\text { Septyan }\end{array}$ & $\begin{array}{l}\text { Disrespectfully service in speaking, like to shout at the } \\
\text { patient's family, please give a warning }\end{array}$ & Poor \\
\hline Alpajri & $\begin{array}{l}\text { Waiting for the doctor to go to poly for treatment for a long } \\
\text { time. Even though we registered since } 08.00 \text {, we can at } 12.00\end{array}$ & Poor \\
\hline Wahyu & $\begin{array}{l}\text { We arrived at the hospital at } 12.00 \text {. But the registration is } \\
\text { closed. Even though the location of our house is far away. }\end{array}$ & Poor \\
\hline Riki & $\begin{array}{l}\text { We have to take a turn for the registration, it is finished at } 12 \\
\text { pm. The poly ignored my registration because the doctor had } \\
\text { come home, so I was told to come back tomorrow. }\end{array}$ & Good \\
\hline Saipul & $\begin{array}{l}\text { Doctors are not on time, please confirmed the schedule so } \\
\text { that patients do not wait too long. }\end{array}$ & Poor \\
\hline Imam & $\begin{array}{l}\text { We were visitors to the hospital, we slipped in the parking lot } \\
\text { because the road was damaged. }\end{array}$ & Poor \\
\hline Bondan & $\begin{array}{l}\text { The doctor only stay for an hour in the polyclinic, while the } \\
\text { patients who are going to consult are full. }\end{array}$ & Poor \\
\hline $\begin{array}{l}\text { As- } \\
\text { Syahrofi }\end{array}$ & $\begin{array}{l}\text { To avoid a long and many queues, we recommend patients } \\
\text { who register in their fields/places of treatment so that they } \\
\text { are quickly treated. }\end{array}$ & Adequate \\
\hline Tasya & BPJS and General medical services are still very slow. & Adequate \\
\hline Zaiza & $\begin{array}{l}\text { The Specialist doctor entered to check the patient for a long } \\
\text { time. It is not appropriate for children if they have to wait for } \\
\text { a long time. We cannot stand }\end{array}$ & Poor \\
\hline Fadhilah & $\begin{array}{l}\text { The specialist doctor came in a very long time, so we could not } \\
\text { go back to school. }\end{array}$ & Poor \\
\hline Joni & $\begin{array}{l}\text { The doctor did not come to poly again, after the midday } \\
\text { prayer, we were asked to return tomorrow }\end{array}$ & Poor \\
\hline Alfatah & $\begin{array}{l}\text { We arrived at } 11.00 \text { a.m. The nurse said the doctor was } \\
\text { operating. We wait until 3:00 p.m. }\end{array}$ & Poor \\
\hline Zola & $\begin{array}{l}\text { Doctor's admission hours are unclear. The nurse said at } \\
\text { 10:00. But it turns out the doctor came in at } 12.00 \text {. }\end{array}$ & Poor \\
\hline Sutanyo & Get treatment on Saturday, at 11.00 , the doctor is not in place. & Poor \\
\hline Rani & $\begin{array}{l}\text { Arriving at the hospital at 11:30. But we were told to come } \\
\text { back tomorrow for treatment, even though the distance from } \\
\text { home to hospital was very far }\end{array}$ & Poor \\
\hline
\end{tabular}

a. Stakeholder perception about improving service hours policy

After processing the data through the results of the suggestion box, it can be concluded that service users felt dissatisfied with the hours of service applied in H. Hanafie Hospital, there- fore, these problems must be followed up immediately.

In this case, conducting an internal meeting of the hospital leadership, and all outpatient units must be done, from the results of the meeting, the head of the hospital 
issued a policy that regulated the hours of service in the outpatient unit.

The results showed that the majority of stakeholders by $70.59 \%$ agreed with the improvement of service hour policy. Some informants said that $29.41 \%$ of the improvement in service hour policy could be implemented but it needed the supervision.

\section{b. Impact of improved service hours on the performance of officers}

This study found that $76.47 \%$ of informants reported improvement under the service hour policy. The number of visits increased, the workload also increased, requiring good attitudes and motivation from officers.

\section{c. Patient Satisfaction After Im- proving Service Hour Policies}

This study showed that most of the informants by $88.24 \%$ stated that they were satisfied with the improvement in service hour policy. A small portion of Informants by $11.76 \%$ were not satisfied with the improvement in service hour policy.

\section{DISCUSSION}

\section{Factors that affect individual performance}

Individual performance was influenced by several factors, including knowledge, skills, abilities, motivations and roles. In line with this, each individual was responsible for performance, there were five main responsibilities that must be fulfilled by each individual in the organization to achieve the desired performance results. These responsibilities were: (1) giving commitment to achieve goals;
(2) asking for feedback on the performance; (3) conducting open and regular communication with their managers; (4) obtaining performance data and share that data with other parties; (5) preparing themselves for evaluation of the performance they have achieved.

\section{Factors affecting the quality of service}

Maintaining service quality concerning patient satisfaction was strongly influenced by various factors/ elements that support to maintain the quality, these elements were: (1) input elements; (2) environmental elements; (3) process elements; (4) output elements.

Patient satisfaction increased after the introduction of a new service hour policy. Further supervision was needed in the implementation so that the policy has a good impact on the community and a good impact on service providers so that the services provided were truly quality services. Improvement of the service hour policy started from input, process and output, as a chain that cannot be separated, because it influenced one another with good quality and services.

\section{REFERENCE}

Azwar A (1994). Program Menjaga Mutu Pelayanan Kesehatan, Cetakan II Yayasan Penerbit Ikatan Dokter Indonesia, Jakarta.

Corputty LJ, Kusnanto H, Lazuardi L (2013). Dampak Kebijakan Pelayanan Kesehatan Gratis Terhadap Kepuasan Pasien Dalam Menerima Pelayanan 
Kesehatan Puskesmas di Kota Ambon. Jurnal Kebijakan Kesehatan Indonesia 2(2).

Dwiyanto A (2005). Mewujudkan Good Governance Melalui Pelayanan Publik, Gadjah Mada University Press, Yogyakarta.

Hardiyansyah (2011). Kualitas Pelayanan Publik: Konsep, Dimensi, Indikator dan Implementasinya. Yogyakarta: Gava Media.

Keputusan Bupati Bungo (2017). Penetapan Besaran Pemotongan Lainnya Berkenaan dengan Pemberian Tambahan Penghasilan Kepada Pegawai Negeri Sipil di Lingkungan Pemerin- tahan Kabupaten Bungo No 107/BPKAD.

Keputusan Direktur RSUD H.Hanafie Muara Bungo (2018). Kebijakan Jam Pelayanan Pasien Rawat Jalan (Poliklinik).

Lestari Y, Herbasuki N(2017). Analisis Tingkat Kepuasan Pasien Rawat Jalan. Departemen Administrasi Publik. Fakultas Ilmu Sosial dan Ilmu Politik. Universitas Diponegoro.

Sugiyono (2009). Metode Penelitian Kuantitatif, Kualitatif, dan R\&D. Bandung: Alfabeta.

Sugiyono (2012). Metode Penelitian Kuantitatif, Kualitatif, dan R\&D. Bandung: Alfabeta. 